\title{
KAJIAN MEDIA MASSA: REPRESENTASI GIRL POWER WANITA MODERN DALAM MEDIA ONLINE \\ (Studi Framing Girl Power dalam Rubrik Karir dan Keuangan Femina Online)
}

\author{
Gita Aprinta E.B \\ (gita.sudjarwo@yahoo.com) \\ Peneliti Online Media
}

\begin{abstract}
The working women isn't a new phenomenon in the modern society. Through their carrier, they try to find meaning, identity and achievement that bring confidence to their life. However, there is still a problem regarding the bias gender related to the quality and capabilities of women in the work field. Femina as one of women magazine realize that women also need information that can help them to attributes and give the self identity in the role of society. This research aim at how Femina talks about girl power in several articles by Gamson and Modigliane framwork in two core structures and condensing symbol frames.
\end{abstract}

Keywords: working women, media online, girl power, framing.

\section{PENDAHULUAN}

\section{Latar Belakang}

Fenomena wanita bekerja bukan merupakan hal baru dalam masyarakat. Perkembangan jaman lah yang membuat tidak adanya batasan bagi seorang wanita untuk bekerja. Dengan bekal pendidikan yang cukup, keterampilan memadai dan di dukung oleh lingkungan, maka seorang wanita dapat mengembangkan diri melalui pekerjaannya. Menurut Bhatnagar dan Radjadhyaksha, abad 21 dicirikan dengan persaingan di dunia kerja dan peluang tersebut sangat terbuka bagi para wanita ${ }^{\mathrm{T}}$. Bagi wanita sendiri, bekerja merupakan kesempatan untuk dapat mengaktualisasikan diri. Bekerja memungkinkan seorang wanita mengeskpresikan dirinya sendiri dengan cara yang kreatif dan produktif untuk menghasilkan sesuatu yang mendatangkan kebanggan terhadap diri sendiri, terutama jika prestasinya tersebut mendapatkan penghargaan dan umpan balik yang positif. Melalui bekerja, wanita berusaha menemukan arti dan identitas dirinya, dan pencapaian tersebut mendatangkan rasa percaya diri dan kebahagiaan. $^{2}$

Tidak disangkal jikalau dalam bekerja, kerap kali terdapat problematika. Begitupun dengan wanita bekerja, problematika yang paling sering muncul adalah masih banyak terdapat bias gender dalam memandang dan memperlakukan pekerja wanita. Problem tersebut biasanya berkaitan dengan kualitas dan kemampuan wanita dalam bekerja. Dalam sebuah perusahaan, kesempatan untuk menaiki jenjang karir ataupun mendapatkan pendidikan tambahan bagi wanita hanya berkisar $10 \%$ walaupun jumlah wanita bekerja kini mengalami kenaikan yang siginifikan semenjak tahun 1980an, bahkan jumlahnya berbanding 3:1 dengan pekerja pria secara merata di perusahaan perusahaan, khususnya sektor manufaktur.

Femina sebagai salah satu media wanita, menangkap fenomena dan problematika di atas sebagai sebuah issue yang perlu diangkat dan diutarakan di

\footnotetext{
${ }^{2}$ Rini, JF, 2002.
}

\footnotetext{
${ }^{1}$ Bhatnagar dan Rajadhyaksha, 2001.
} 
permukaan. Sebagai sebuah media massa, Femina tampaknya menyadari bahwa wanita juga memerlukan informasi yang dapat menjadi atribut identitas diri yang membantu peranannya dalam masyarakat. Penerbitan majalah wanita sebenarnya bukan merupakan hal baru di Indonesia. Pada tahun 1960 - 1970an, masyarakat Indonesia pernah mengenal majalah Selecta dan Varia. Seiring dengan perkembangan jaman pemasar pun menyadari bahwa wanita merupakan pasar potensial yang sangat besar. Oleh karenanya tidak salah jika di Indonesia terdapat sekitar 20 majalah yang ditujukan untuk kaum wanita. Sebut saja, Femina, Kartini, Cosmopolitan Indonesia, Gadis, Dewi, Kawanku, Seventeen, Cosmopolitan Girl, Harper's Bazaar Indonesia, Good Housekeeping, Cita Cinta, Swara Cantika, Lisa, Prodo, Nyonya dan lain-lain ${ }^{3}$.

Majalah Femina sejak tahun 1971 sudah berkecimpung dalam media informasi wanita dan menyajikan tentang informasi akan kebutuhan wanita, yang juga disertai kiat-kiat dalam memecahkan persoalan seputar wanita. Femina tidak hanya hadir dalam bentuk media cetak, namun juga dalam bentuk digital media atau media online dengan harapan dapat dibaca setiap saat bahkan ketika berada di tempat kerja sekalipun. Femina Online merupakan versi digital dari majalah Femina cetak sehingga artikel dan informasi yang disajikan tidak berbeda sama sekali dengan versi cetaknya. Sebagai media dengan segmentasi khusus wanita, Femina sangat concern terhadap issue - issue yang berkaitan dengan wanita terutama dalam dunia kerja atau karir. Sesuai dengan konsep majalah pada umumnya, majalah memiliki fungsi sebagai bahan bacaan dan sebagai bahan bacaan majalah haruslah memenuhi suatu fungsi yaitu untuk memberikan jawaban kepada rasa ingin tahu pembacanya.

\footnotetext{
${ }^{3}$ Kasali, Rhenald, 1998.
}

Majalah - majalah diciptakan untuk membawa berita aktual secara tepat, maka majalah juga harus dipersiapkan dalam waktu singkat, namun isinya harus cukup banyak, bervariasi dan penyajiannya harus menarik. ${ }^{4}$

Majalah wanita adalah majalah yang mempunyai tugas khusus, yaitu menciptakan dunia yang khas untuk perempuan $^{5}$. Oleh karena itu rubrik rubrik yang ada memang khusus disediakan untuk wanita, seperti misalnya rubrik memasak, rubrik kecantikan, rubrik rumah tangga dan lain-lain. Mengakuisisi sebagai 'Gaya Hidup Masa Kini, Inspirasi bagi Wanita Modern Indonesia' Femina mengakomodasi keingin-tahuan pembacanya lewat rubrik Issue Wanita yang berisi berbagai rubrik-rubrik kecil salah satu diantaranya adalah rubrik Karir dan Keuangan yang diperuntukkan khusus untuk wanita bekerja.

Sebagai media yang diperuntukan bagi Wanita Modern Indonesia sesuai dengan jargonnya, Femina memang merupakan media yang ditargetkan untuk produk produk kelas menengah ke atas yang bergaya hidup perkotaan atau modern. Berbeda dengan majalah sejenis yaitu Kartini yang cenderung menampilkan pengalaman wanita yang berjuang dalam melawan pengalaman hidup Femina justru menampilkan kisah sejati yang dialami wanita dalam berbagai bidang pekerjaan. Target segmentasi pembaca Femina juga memiliki kelas sosial ekonomi terbaik atau tertinggi, sehingga sebagian besar merupakan wanita yang cenderung lebih mandiri atau memiliki bargaining position yang kuat dalam rumah tangganya. Mereka umumnya menghargai karir atau pernah bekerja dan menghargai waktu ${ }^{6}$.

\footnotetext{
${ }^{4}$ Nirwana, Jurnal Vol. 3, No. 2, Juli 2001.

${ }^{5}$ Ibid, Nirwana.

${ }^{6}$ Kasali, Rhenald, 1998.
} 
Adapun ciri - ciri wanita modern yang merupakan jangkauan Femina, melalui survey tahun 1996/1997 adalah sebagai berikut ${ }^{7}$ :

- Wanita muda, bergaya hidup kota besar

- Berbelanja di Departement Store, pasar swalayan/mal

- Umumnya berpendidikan tinggi, minimal D3/akademi

- Membeli baju jadi (office dress/casual), namun untuk menghadiri pesta mereka biasanya masih mengandalkan tukang jahit tertentu, dan sesekali membeli baju rancangan desainer.

- Merawat kecantikan di salon.

- Memiliki tabungan dengan kartu ATM

- Akhir pekan melakukan makan siang/malam di luar (restoran) dan atau menonton sinema

- Kebanyakan single atau menunda usia perkawinan sampai usia 30-an

Melalui rubrik Karir dan Keuangan yang menjadi rubrik di dalam rubrik Issue Wanita, Femina merepresentasikan girl power atau independensi wanita di tempat kerja. Bahwa wanita juga bisa memiiki posisi yang sama dengan pria, tidak hanya sekedar menjadi bawahan, kalaupun menjadi bawahan, mereka adalah bawahan yang mempunyai kualitas yang patut diperhitungkan, tidak lemah, cerdas, dapat mengatasi tekanan di tempat kerja dan lain sebagainya. Ungkapan "Girl Power" adalah istilah pemberdayaan, mengungkapkan fenomena budaya pada pertengahan-akhir 1990-an hingga awal 2000-an, dan juga dikaitkan dengan gelombang ketiga feminisme. Istilah ini dipopulerkan oleh Spice Girls pada pertengahan hingga akhir 1990-an ${ }^{8}$.

\footnotetext{
${ }^{7}$ Ibid, Kasali, Rhenald.

${ }^{8}$ Karlyn, Kathleen Rowe, 2003.
}

Sedangkan dalam kamus Oxford English Dicitionary, Girl Power didefinisikan sebagai :

Power exercised by girls; spec. a selfreliant attitude among girls and young women manifested in ambition, assertiveness, and individualism. Although also used more widely (esp. as a slogan), the term has been particularly and repeatedly associated with popular music; most notably in the early 1990s with the briefly prominent 'riot girl' movement in the United States (cf. RIOT GIRL n.); then, in the late 1990s, with the British all-female group The Spice Girls.

Tampaknya Femina sadar betul bahwa representasi wanita yang ditampilkan melalui rubriknya tersebut dapat dijadikan pilihan bacaan oleh target pembaca atau bahkan mungkin sebagai acuan bagi para pembacanya. Kiat-kiat atau solusi pemecahan masalah yang selalu menyertai di setiap artikelnya dimaksudkan untuk dapat mendorong kepercayaan diri wanita dalam menghadapi masalah dan mengambil keputusan. Bahwa tidak ada suatu permasalahan apapun di tempat kerja yang tidak dapat dipecahkan. Artikel - artikel tersebut di buat dengan tatanan kata dan kalimat yang menegaskan sosok kekuatan wanita, bahkan dalam judul pun telah terlihat penekanan sebagai berikut, 'Bukan Sembarang Sekretaris' dan '3 Wanita Penikmat Teknologi'

Hal ini disebabkan oleh karena para wanita berkecenderungan memilih sesuatu menurut konsep dirinya, majalah yang dianggap mencerminkan dirinya. Ia mengidentifikasi dirinya dengan majalah dan pengasuhnya, karena ia merasa keingintahuannya terpenuhi dan karena ia merasa bahwa majalahnya mengandung petunjuk - petunjuk yang berharga 
baginya untuk masalahnya pada waktu ini dan untuk masa mendatang ${ }^{9}$.

Femina mungkin merefleksikan realitas yang ada di masyarakat, mengenai keperkasaan wanitta namun bisa jadi Femina juga menciptakan realitas bagi kaum wanita itu sendiri, seperti yang dikatakan oleh Debra A Yatim dalam tulisannya yang berjudul Perempuan dan Media Massa, Oleh Pria untuk Pria bahwa di satu pihak, betul media jadi cermin bagi keadaan di sekelilingnya. Namun, di pihak lain, ia juga membentuk realitas sosial itu sendiri. Lewat sikapnya yang selektif dalam memilih hal - hal yang ingin diungkapkannya, dan juga lewat caranya menyajikan hal - hal tersebut, media memberikan intepretasi, bahkan membentuk realitasnya sendiri ${ }^{10}$.

Dengan demikian, dapat dilihat bahwa Femina dalam rubriknya tersebut mempunyai peranan yang penting dalam merepresentasikan wanita modern yang independen, memiliki kekuatan atau keperkasaan atau kerap kali disebut girl power dalam dunia kerja.

\section{Pertanyaan Penelitian}

Melihat fenomena di atas, dapat ditarik suatu kesimpulan permasalahan bagaimana Femina membingkai girl power pada wanita perkotaan modern dalam dunia kerja pada sajian rubrik karir dan keuangan khususnya dalam beberapa artikel: 'Bukan Sembarang Sekretaris', '3 Wanita Penikmat Teknologi?'

\section{Tujuan Penelitian}

Untuk mengetahui bagaimana bentuk framing Femina mengenai girl power wanita perkotaan modern dalam rubrik Karir dan Keuangan menurut kerangka framing Gamson dan Modigliani dalam dua struktur core framse dan condensing symbol.

\footnotetext{
${ }^{9}$ Opcit, Nirwana.

10 Idi Subandi Ibrahim dan Hanif Suranto (Ed), Media dan Wanita.
}

\section{Signifikansi Penelitian \\ 4.1.Signifikansi Akademis}

Penelitian ini menghasilkan sebuah analisis yang relevan dengan realitas yang ada sebagai kontribusi yang diharapkan dapat memperkaya studi komunikasi mengenai representasi perempuan di media. Penelitian mengenai perempuan di Indonesia pun sebenarnya sudah cukup banyak dilakukan, baik penelitian yang dilakukan pada media maupun pada perempuan itu sendiri. Namun biasanya penelitian yang terkait dengan perempuan dalam media selalu berada pada ranah kekerasan simbolik perempuan dalam media dan brand image.

Seluruh penelitian tersebut mendorong peneliti untuk melakukan penelitian lain mengenai perempuan, khususnya masalah girl power yang ditampilkan dalam Femina Online. Hal ini menjadi menarik karena girl power merupakan sebuah fenomena yang sampai sekarang masih menjadi topik utama dalam hal kesejajaran pria dan wanita. Dengan demikian, penelitian ini diharapkan mampu memperkaya wacana mengenai representasi perempuan dalam media massa.

\subsection{Signifikansi Praktis}

Hasil penelitian ini diharapkan dapat bermanfaat untuk memahami permasalahan girl power wanita. Dengan mengetahui representasi girl power, setidaknya penelitian ini mencoba untuk mengetengahkan tentang bagaimana wanita mempunyai peranan dan kemampuan yang cukup hebat yang digambarkan melalui media massa.

\section{Tinjauan Pustaka}

\subsection{Teori Framing}

Framing pertama kali dilontarkan oleh Beterson (Sudibyo, 199a:23), yang dimaknai sebagai struktur konseptual atau perangkat kepercayaan yang mengorganisir pandangan politik, kebijakan, dan wacana, serta yang menyediakan kategori - kategori standar untuk mengapresiasi realitas. 
Sementara menurut Goffman, frame diandaikan sebagai kepingan - kepingan perilaku (strips of behavior) yang membimbing individu dalam membaca realitas.

Dalam studi komunikasi, framing digunakan untuk membedah cara - cara atau ideologi media saat mengkonstruksikan fakta. Analisis ini mencermati strategi seleksi, penonjolan dan pertautan fakta ke dalam berita agar lebih bermakna, lebih menarik, lebih berarti dan lebih diingat untuk mengiring intepretasi khalayak sesuai perspektifnya. Dengan kata lain, framing adalah pendekatan untuk mengetahui perspektif atau cara pandang yang digunakan oleh wartawan untuk menyeleksi isu dan menulis berita. Cara pandang atau perspektif itu pada akhirnya menentukan fakta yang diambil, bagian mana yang ditonjolkan dan dihilangkan, serta hendak dibawa ke mana berita tersebut (Eriyanto, 1999:21). Sehingga, berita menjadi manipulatif dan bertujuan mendominasi keberadaan subjek sebagai sesuatu yang legitimate, objektif, alamiah, wajar, atau tak terelakkan (Imawan, 2000:66).

Gitlin mendefiniskan frame sebagai seleksi, penegasan, dan ekseklusi yang ketat. Ia menghubungkan konsep tersebut dengan proses memproduksi wacana berita dengan menyatakan, "Frames memungkinkan para jurnalis memproses sejumlah besar informasi secara cepat dan rutin, sekaligus mengemas informasi demi penyiaran dan efisien kepada khalayak". Sementara Gamson dan Modigliani menyebut cara pandang tersebut sebagai kemasan (package) yang mengandung konstruksi makna atas peristiwa yang akan diberitakan. Menurut mereka, frame adalah cara pandang atau bercerita atau gugusan ide - ide yang terorganisir sedemikian rupa dan menghadirkan konstruksi makna peristiwa - peristiwa yang berkaitan dengan obyek suatu wacana (Eriyanto 1999: 21-22).

\subsection{Teori Representasi}

Representasi menurut Stuart Hall mengandung 2 pengertian yaitu, Pertama, representasi mental, adalah konsep tentang sesuatu yang ada di kepala kita masing-masing atau disebut juga sebagai peta konseptual. Representasi mental ini membentuk sesuatu yang abstrak. Kedua, representasi bahasa, representasi bahasa berperan penting dalam konstruksi makna. Konsep abstrak yang ada dalam kepala kita harus diterjemahkan dalam bahasa yang lazim, supaya kita dapat menghubungkan konsep-konsep dan ideide kita tentang suatu tanda dan simbolsimbol tertentu ${ }^{11}$.

Proses pertama memungkinkan kita untuk memaknai dunia dengan mengkonstruksi seperangkat rantai korespondensi antara sesuatu dengan sistem 'peta konseptual' kita. Dalam proses kedua, kita mengkonstruksi seperangkat rantai korespondensi antara 'peta konseptual' dengan bahasa atau simbol yang berfungsi merepresentasikan konsep-konsep kita tentang sesuatu. Relasi antara 'sesuatu', 'peta konseptual', dan 'bahasa/simbol' adalah jantung dari produksi makna lewat bahasa. Proses yang menghubungkan ketiga elemen ini secara bersama-sama itulah yang kita namakan: representasi.

Jadi dengan demikian representasi adalah proses sosial dari representing sekaligus produk dari representing itu sendiri. Representasi menunjuk pada proses maupun produk dari pemaknaan suatu tanda. Representasi adalah konsep yang digunakan dalam proses sosial pemaknaaan melalui sistem penandaan yang tersedia, seperti dialog, video, film, teks, fotografi dan sebagainya. Representasi adalah produksi makna melalui bahasa.

Untuk dapat menjelaskan bagaimana produksi makna hingga penggunaan

\footnotetext{
${ }^{11}$ Hall, Stuart. 1997.
} 
dalam konstruksi sosial, Hall memetakannya menjadi tiga teori representasi (Hall, 1997).

Pertama, pendekatan Reflektif; bahasa berfungsi sebagai cermin, yang merefleksikan makna yang sebenarnya dari segala sesuatu yang ada di dunia. Dalam pendekatan reflektif, sebuah makna tergantung pada sebuah objek, orang, ide atau peristiwa di dalam dunia nyata. Bahasapun berfungsi sebagai cermin yaitu untuk memantulkan arti sebenarnya seperti yang telah ada di dunia. Namun tanda visual membawa sebuah hubungan kepada bentuk dan tekstur dari objek yang direpresentasikan.

Kedua, pendekatan intensional; kita menggunakan bahasa untuk mengkomunikasikan sesuatu sesuai dengan cara pandang kita terhadap sesuatu. Pendekatan makna yang kedua dalam representasi yang mendebat sebaliknya. Pendekatan ini mengatakan bahwa sang pembicara, penulis atau siapapun yang mengungkapkan pengertiannya yang unik ke dalam dunia melalui bahasa.

Ketiga, pendekatan Kontruksi: kita mengkonstruksi makna lewat bahasa yang kita pakai. Ini adalah pendekatan ketiga untuk mengenali publik, karakter sosial dan bahasa. Sistem representasi dari pendekatan konstruksi ini meliputi suara, gambar, cahaya pada foto, coretan-coretan yang kita buat atau representasi dapat juga disebut sebagai praktek dari jenis kerja yang menggunakan obyek material. Namun demikian makna tidak tergantung pada kualitas material tanda, tetapi lebih kepada fungsi simbolik.

\subsection{Media Massa dan Girl Power}

Sejalan dengan fungsi media massa yang diungkapkan oleh McQuail (2001) yaitu sebagai pemberi informasi, pemberi identitas pribadi, sarana intergrasi dan interaksi sosial dan sebagai sarana hiburan, maka majalah wanita berfungsi sebagai bahan bacaan yang dapat memberikan jawaban atas rasa ingin tahu pembaca. Myra M. Sidharta merinci tugas majalah wanita yang berkenaan dengan fungsinya menjadi dua tugas yaitu ${ }^{12}$ :

1. Sebagai sumber informasi, majalah adalah pencipta iklim mental yang diperlukan untuk menjawab pertanyaan - pertanyaan wanita yang ingin tahu dan yang kurang mempunyai kepercayaan diri untuk menghadapi tantangan - tantangan dunia ini.

2. Majalah wanita mempunyai tugas sosial - edukatif. Mengingat pengaruhnya sebagai pencipta citra wanita yang diterima oleh kaum wanita di sini, maka tugas tersebut meliputi: mengubah gaya hidup konsumtif menjadi gaya hidup aktifkreatif; meningkatkan selera pembaca, dari bahan bacaan menghibur dan sensasional provokatif menjadi bahan bacaan berpikir dan berarti; mendidik kaum wanita menjadi wanita yang mengetahui hak-hak dan batas - batas kewajibannya di dunia yang didominasi oleh kaum pria; mendidik kaum wanita untuk menghadapi tugastugas dan masalah-masalah dikemudian hari, karena jurang generasi yang terjadi dewasa ini, adalah kurang persiapan generasi tua menghadapi generasi muda; dan membantu para ibu untuk mempersiapkan putra-putri mereka untuk menghadapi masalah di masa mendatang.

Girl Power (kekuasaan perempuan) sebagai sebuah fenomena pemberdayaan feminisme muncul untuk pertama kalinya di media massa melalui figur figur tokoh atau artis kenamaan dalam film Charlies Angels, Mulan, Sabrina the Teenage Witch, The Power Puff Girls, Lara Croft dan juga melalui lirik-lirik lagu Britney

\footnotetext{
12 Idi Subandi Ibrahim dan Hanif Suranto (Ed),
} Media dan Wanita. 
Spears $^{13}$. Visi girl power saat itu masih terbatas pada penciptaan pahlawan perempuan dalam budaya popular. Namun demikian sejatinya indikasi kekuasaan perempuan (girl power) sudah muncul dalam mitos atau legenda-legenda di masa lalu, seperti Dewi Satyawati dalam cerita Pandawa dan Kurawa.

Girl Power datang seiring dengan gelombang ketiga feminisme. Gelombang ketiga feminisme ini memungkinkan perempuan untuk mendefinisikan feminisme untuk diri mereka sendiri dengan memasukkan identitas mereka menurut kepercayaan dan perspektif mereka sendiri. Secara sederhana dapat girl power dapat dideskripsikan sebagai sebuah mental yang tidak mau kalah sama laki-laki, setiap kemauannya, dia sendiri yang akan mewujudkan dengan kemampuannya sendiri.

\section{Metodologi Penelitian \\ 6.1. Pendekatan Penelitian}

Pendekatan yang digunakan dalam penelitian ini adalah pendekatan kualitatif. Pendekatan kualitatif adalah suatu proses penelitian dan pemahaman yang berdasarkan pada metodologi yang menyelidiki suatu fenomena sosial dan masalah manusia. Pada pendekatan ini, peneliti membuat suatu gambaran kompleks, meneliti kata-kata, laporan terinci dari pandangan responden, dan melakukan studi pada situasi yang alami (Creswell, 1998:15).

Pendekatan kualitatif biasanya digunakan untuk dapat mengetahui makna yang tersembunyi dari sebuah fenomena sosial, memahami interaksi sosial, untuk mengembangkan teori dan juga digunakan untuk memastikan keabsahan data. Menurut Baxter dan Babbie dalam penelitan kualitatif haruslah memuat datadata eksplisit, menggunakan metode yang sistematik, dan adanya laporan sebagai

\footnotetext{
${ }^{13}$ Hopkins, Susan. Girl Heroes: The New Force In Popular Culture.
}

intepretasi data tekstual. Bagi penelitian kualitatif, peneliti merupakan instrumen kunci sehingga harus dapat merumuskan pertanyaan sedemikian rupa, menganalisa dan mengkonstruksikan obyek penelitian menjadi lebih jelas.

\subsection{Paradigma Penelitian}

Penelitan ini meletakkan pijakan pada paradigma konstruktivisme. Menurut Guba dalam Creswell (1998), dalam paradigma konstruktivis realitas sosial yang diamati tidak dapat digeneralisasikan pada semua orang. Bahasa tidak lagi hanya dilihat sebagai alat untuk memahami realitas objektif belaka yang dipisahkan dari subjek sebagai penyampai pernyataan. Dalam pardigma konstruktivis ini menganggap bahwa subjek adalah aktor utama atau faktor sentral dalam kegiatan wacana serta hubunganhubungan sosialnya.

Penelitian yang dilakukan, digunakan untuk memahami, menjelaskan dan merekonstruksi berbagai makna tindakan sosial yang ada dalam kehidupan manusia. Tidak ada realitas yang bersifat obyektif dalam pandangan konstruksi, fakta - fakta yang ada sudah dikonstruksikan sedemikian rupa sehingga memproduksi suatu produksi realitas berita tertentu. Demikian juga dengan realitas yang dibangun oleh suatu media massa tentu tidak akan bisa lepas dari konteks yang melatar belakangi pembentuk teks berita tersebut. Penelitian dengan paradigma konstruktivisme ini untuk mengetahui bagaimana pihak redaksi Femina online melakukan konstruksi girl power pada wanita perkotaan modern dalam dunia kerja.

\subsection{Metode Penelitian}

Metode penelitian yang digunakan adalah analisis framing sebagai perangkat penelitian. Framing, dalam pandangan Entman secara konsisten menawarkan sebuah cara untuk mengungkap the power of a communication text. Analisis framing sendiri dapat menjelaskan dengan cara 
yang tepat pengaruh atas kesadaran manusia yang didesak oleh transfer ( atau komunikasi) informasi dari sebuah lokasi seperti pidato, ucapan atau ungkapan, news report dan novel ${ }^{14}$.

Peneliti akan menganalisa artikel tentang girl power dalam Femina Online dan menyimpulkan hasil temuan dari analisis tersebut. Model framing Gamson dan Modigliani dipilih karena model ini didasarkan pada pendekatan konstruksionis yang melihat representasi media - berita dan artikel, terdiri dari seperangkat intepretatif yang mengandung konstruktif makna tertentu dan model ini sesuai dengan penelitian yang hendak dilakukan oleh peneliti dalam melihat konstruksi girl power oleh Femina Online. Dalam model framing Gamson dan Modigliani ini terdapat dua rumusan struktur; core frame dan condensing simbol.

\subsection{Teknik Pengumpulan Data}

Data primer yang akan digunakan dalam penelitian ini adalah artikel artikel dalam Rubrik Karir dan Keuangan Femina Online. Sebagai data pendukung adalah data-data yang dikumpulkan tentang subyek penelitian yaitu Group Femina. Kemudian untuk memperlancar proses dalam analisis, peneliti melakukan studi pustaka untuk memperoleh data data tambahan.

Adapun artikel yang akan diteliti adalah artikel 'Bukan Sembarang Sekretaris', '3 Wanita Penikmat Teknologi'.

\subsection{Teknik Analisa Data}

Data - data yang dikumpulkan oleh peneliti selanjutnya akan dianalisis menggunakan perangkat framing model Gamson dan Modigliani sebagai berikut ${ }^{15}$ :

\footnotetext{
${ }^{14}$ Alex Sobur, 2002.

15 Gamson, William A and Modgiliani, Andrew 1998.
}

a. Core Frames: gagasan sentral untuk memberikan pengertian yang relevan terhadap peristiwa, dan mengarahkan makna issu yang dibangun oleh condensin symbol.

b. Condensing Symbol: hasil pencermatan terhadap interaksi simbolik yaitu framing devices dan reasoning devices sebagai dasar digunakannya perspektif. Simbol dalam wacana terlihat transparan bila dalam dirinya menyusup perangkat bermakna yang mampu berperan sebagai panduang menggantikn sesuatu yang lain.

c. Struktur framing devices meliputi metaphor, exemplar, catchphrases depiction dan visual image menekankan pada aspek bagaimana melihat suatu issu.

d. Struktur reasoning devices menekankan pada aspek pembenaran terhadap cara melihat issu yaitu roots dan appeal to principle.

Methaphors dipahami sebagai cara memindah makna dengan merealisasikan 2 fakta melalui analogi atau memakai kiasan dengan menggunakan kata - kata seperti; ibarat, bak, sebagai, umpama, laksana atau gaya bahasa perbandingan yang paling singkat, padat dan tersusun rapi.

Exemplars mengemas fakta tertentu secara mendalam agar memiliki bobot makna lebih baik untuk dijadikan rujukan. Posisinya sebagai pelengkap bingkai inti dalam kesatuan berita untuk membenarkan perspektif.

Catchphrases, istilah, bentukan kata atau frase khas. Cerminan fakta yang merujuk pemikiran atau semangat tertentu, biasanya jargon, slogan atau semboyan.

Depictions, penggambaran fakta dengan memakai istilah, kalimat konotatif agar khalayak terarah pada citra tertentu.

Visual Images, pemakaian foto, diagram, grafis, label, kartun dan sejenisnya untuk mengekspresikan kesan, misal perhatian atau penolakan, dibesarkan - dikecilkan, ditebalkan - dimringkan, serta pemakaian warna. 
Roots, pembenaran issu dengan menghubungkan suatu objek atau lebih yang dianggap menjadi sebab timbulnya atau terjadinya hal yang lain yang bertujuan untuk membenarkan penyimpulan fakta berdasarkan hubungan sebab akibat yang digambarkan atau dibeberkan.

Appeal to principle, pemikiran, prinsip, klaim moral sebagai argumentasi pembenar membangun berita berupa pepatah, cerita rakyat, mitos, doktrin, ajaran dan sejenisnya.

Consequences atau efek adalah konsekuensi yang ditimbulkan dari bingkai tersebut.

\subsection{Keabsahan Data}

Pemeriksaan keabsahan data dalam penelitian ini akan dilakukan dengan cara analisis triangulasi teknik. Peneliti akan menganalisis dengan meneliti kebenarannya dengan data empiris yang dapat meningkatkan pemahaman peneliti terhadap apa yang ditemukan dengan memanfaatkan jurnal, dokumentasi dan sebagainya.

\subsection{Kriteria Kualitas Penelitian}

Menurut Patton (2002:546), kriteria kualitas penelitian untuk bentuk penelitian konstruksi sosial dan konstruktivis adalah sebagai berikut :

- Subjektifitas diakui (dibahas dan menjadi bagian bias), Kepercayaan (trustworthiness),

Keaslian (authenticity), Triangulasi (menangkap dan menghargai berbagai perspektif), Refleksvitas, Praxis, Kekhususan (melakukan keadilan untuk integritas keunikan masingmasing kasus), Pengertian (verstehen), Kontribusi terhadap dialog.

Lincoln dan Guba (1986) menyatakan bahwa penelitian konstruktivis memerlukan kriteria yang berbeda dengan yang menggunakan ilmu sosial tradisional. Penekanan dilakukan bahwa penelitan naturalis sebaiknya dinilai dengan dependability (ketergantungan) sebuah proses sistematik yang akan mengikuti dan keaslian (authenticity) merefleksikan kesadaran perspektif seseorang, menghargai perspektif orang lain serta keadilan dalam melukiskan konstruksi pada nilai yang mendasari mereka. Mereka menawarkan perspektif dan mendukung dialog antar perspektif bukan hanya pada satu kebenaran dan prediksi linear.

\section{PEMBAHASAN (HASIL DAN INTEPRETASI PENELITIAN)}

\section{Hasil Penelitian}

Bab ini berisi hasil analisis teks dan intepretasi dari obyek penelitian berdasarkan perangkat framing Gamson dan Modigliani yang terdiri dari framing devices yang meliputi: metaphors, catchphrases, exemplars, depiction, visual image dan reasoning defices yang terdiri dari; roots, appeals of principles dan consequences. Hasil analisis framing terhadap artikel 'Bukan Sembarang Sekretaris' dan '3 Wanita Penikmat Teknologi' menghasilkan gambaran representasi girl power dalam artikel tersebut.

Mengacu pada representasi Stuart Hall, ada dua representasi yang dihasilkan yaitu:

a. Representasi mental, berkaitan dengan konsep girl power itu sendiri

b. Representasi bahasa, yaitu makna yang tercipta dari representasi girl power.

Berdasarkan keseluruhan isi artikel diperoleh bahwa Femina Online merepresentasikan girl power sebagai sebuah kekuasaan wanita dalam kemampuan di bidang kerja masing masing antara lain:

a. Memiliki posisi penting dalam perusahaan;

b. Problem Solver;

c. Garda Perusahaan;

d. Penguasa Informasi; 
e. Mempunyai kemampuan yang tidak kalah dibanding pria bahkan lebih;

f. Modal Feminitas yang menguntungkan.

Berikut adalah bagian-bagian artikel yang mengandung 9 representasi girl power, antara lain:

\subsection{Artikel 1 - Bukan Sembarang Sekretaris (Rubrik Karir dan Keuangan Femina Online Edisi III Bulan Maret 2010)}

Core Frames:

Artikel ini menceritakan bagaimana posisi sekretaris merupakan sebuah profesi yang penting dalam operasional perusahaan karena seorang sekretaris bertindak sebagai wakil pimpinan, yang berada di garda depan, mempunyai wewenang untuk mengambil keputusan atau penyelesaian permasalahan apabila pimpinan tidak ada di tempat. Terdapat bermacam - macam profesi sekretaris sekarang ini, seperti coorporate sekretaris, legal sekretaris, medical sekretaris, dan bahkan di beberapa organisasi ataupun institusi pemerintahan profesi sekretaris merupakan sebuah jabatan tinggi, contoh sekretaris negara, sekretaris kabinet, ataupun sekretaris jendral.

A. Bagian artikel yang menggambarkan representasi posisi penting dalam perusahaan adalah:

Framing Devices:

1. Metaphors:

a. "Ia berperan mengurus segala keperluan bosnya, antara lain mengangkat telepon, menyimpan file dan mengaturt jadwal rapat.". (paragraf 1 baris ke 5)

b. 'Seorang sekretaris akan mewakili bosnya'. (paragraf 4 baris 1)

2. Eksemplar:

a. "Ia bertugas untuk meninjau kebijakan-kebijakan yang berkaitan dengan keluar-masuknya 'harta' kantor.( paragraf 13 baris ke 3) b. Sekaligus, ia juga melihat kebijakan yang berhubungan dengan pembelian dan penjualan barang atau jasa oleh perusahaan". (paragraf 13 baris ke 4)

3. Catchphrase:

a. "Padahal kalau ditinggal sakit sehari saja, kita pasti kalang kabut tidak keruan" (paragraf 1 baris 6)

4. Depiction; -

5. Visual Image: -

Reasoning Devices:

1. Roots:

Sekretaris bukanlah sebuah pekerjaan biasa, dan sekretaris yang umumnya banyak dikerjakan oleh kaum wanita, memiliki posisi tinggi dan bahkan memiliki tugas sebagai peninjau kebijakan dalam perusahaan.

2. Appeal to Principles;

'Padahal kalau ditinggal sakit sehari saja, kita pasti kalang kabut tidak keruan. '(paragraf 4 baris 2 ).

Di sini terdapat klaim moral atau pembenar bahwa tanpa seorang sekretaris, maka operasionalisasi perusahaan akan menjadi kacau. Seorang pimpinan pun akan menjadi kalang kabut apabila sehari bekerja tanpa adanya seorang sekretaris.

3. Consequences:

Anggapan bahwa profesi sekretaris merupakan profesi yang kurang penting dapat dirubah dengan mengetahui profesi sekretaris mempunyai peran dan tugas yang penting dan tidak bisa dianggap sepele, karena keberadaan sekretarislah operasi perusahaan dapat berjalan dengan baik sehari-harinya. Analisa:

Konsep girl power muncul dalam representasi melalui konstruksi bahasa yang ditulis dalam artikel berjudul Bukan Sembarang Sekretaris tersebut. Penggunaan kalimat seperti Ia mengurus segala keperluan bosnya dapat dimaknai sebagai kekuasaan wanita dalam mengatur kegiatan hari per hari pimpinan, sementara 
kalimat Ia bertugas meninjau kebijakankebijakan yang berkaitan dengan 'harta' kantornya menunjukkan suatu pemaknaan bahwa kekuasaan wanita tidak sekedar dalam area hubungan individu antara pimpinan dan bawahan, tetapi juga pada aspek kebijakan perusahaan.

Artikel ini merefleksikan makna yang sebenarnya dari segala sesuatu yang ada di dunia kerja para wanita, melalui penggunaan teks sebagai sebuah bahasa komunikasi dan alat konstruksi sebagai fungsi simbolik kepada publik atau pembaca Femina Online sehingga membentuk representasi bahasa.

B. Bagian artikel yang menggambarkan representasi sekretaris sebagai problem solver:

Framing Devices:

1. Metaphors:

a. 'Bedanya, profesi berjudul 'secretary' harus mempunyai strategi. Misalnya, untuk menjawab berita tidak sedap tadi, seorang corporate secretary harus memikirkan jalan terbaik, agar jawabannya tidak menjadi bumerang". (paragraf 6 baris 2-4)

2. Eksemplar:

a. Misalnya, jika perusahaannya banyak melakukan kerja sama dengan perusahaan di suatu negara asing, sementara negara tersebut sedang ribut-ribut ada kudeta, ia bisa mengeluarkan travel warning". (paragraf 7 baris 1-3)

3. Catchphrase:

a. "Ia juga lebih punya power untuk memberi advice”. (paragraf 7 baris 1)

4. Depiction:

a. 'Bedanya, profesi berjudul 'secretary' harus mempunyai strategi". (paragraf 6 baris 2)

5. Visual Image; -

Reasoning Devices:

1. Roots:

Sebagai problem solver, sekretaris dituntut untuk harus mempunyai strategi, power sebagai penasehat dan memikirkan jalan terbaik untuk setiap pemberitaan yang tidak sedap akan perusahaan tempatnya bekerja sehingga dapat memberikan feedback agar tidak menjadi bumerang bagi perusahaannya.

2. Appeal to Principles:

Klaim moral sebagai seorang yang mempunyai power advicer membuat profesi sekretaris dapat mengeluarkan atau mengambil wewenang dalam keadaan darurat.

3. Consequences:

Seorang sekretaris harus mampu mengambil atau memikirkan jalan keluar terbaik dari sebuah permasalahan yang ada terutama di saat-saat keadaan darurat.

Analisa:

Sebagai problem solver merupakan representasi girl power yang hendak ditampilkan oleh Femina Online. Melalui penekanan pada kalimat memikirkan jalan terbaik, lebih punya power dan mempunyai strategi diharapkan representasi mental bahwa seorang sekretaris juga berperan sebagai problem solver. Kehadiran dan kemampuan yang dimiliki oleh wanita menjadi penyeimbang dalam tataran dunia kerja.

C. Bagian artikel yang menggambarkan representasi sekretaris sebagai garda depan perusahaan adalah:

Framing Devices:

1. Metaphors:

a. 'Seorang sekretaris akan mewakili bosnya'. (paragraf 4 baris 1)

2. Eksemplar:

a. "Misalnya, yang paling sederhana, kalau ada klien yang ingin bertemu sang bos, sekretarislah yang akan menemuinya pertama kali" (paragraf 4 baris 2-3)

b. "Kalau ada berita tidak sedap tentang perusahaan, ia yang akan maju terlebih dahulu untuk menjelaskan kepada publik". (paragraf 4 baris 6-7)

3. Catchprhases: 
a. "Posisinya pun sama, yaitu duduk di garda terdepan". (paragraf 4 baris 1)

b. "Dialah yang akan 'maju' terlebih dulu, dealing dengan perusahaan lain sebagai wakil dari perusahaannya". (paragraf 4 baris 5-6)

4. Depiction; -

5. Visual Image: -

Reasoning Devices:

1. Roots:

Sekretaris merupakan garda terdepan dalam perusahaan. Fakta yang ingin ditonjolkan adaalah bahwa sekretaris merupakan orang pertama yang berhubungan dengan orang-orang yang mempunyai kepentingan terhadap perusahaannya.

2. Appeal to Principles:

Mempertegas profesi sekretaris sebagai profesi yang tidak bisa dipandang remeh atau bukan profesi sembarangan.

3. Consequences:

Efek dari bingkai tersebut, mengharuskan profesi sekretaris untuk selalu siap maju terlebih berhubungan dengan klien atau media mewakili perusahaannya.

Analisa:

Kekuasaan wanita atau girl power tampak sekali pada kewenangan sekretaris untuk menjelaskan kepada publik berkaitan dengan berita baik buruk yang menimpa perusahaan tempat ia bekerja. Hal tersebut diperkuat dengan bingkai sebagai garda depan yang direpresentasikan Femina Online terhadap profesi sekretaris tersebut. Jadi dari artikel di atas didapat bingkai berita, 'bahwa seorang sekretaris itu seperti perisai yang harus selalu berada di garis depan'.

D. Bagian artikel yang menggambarkan represetasi sekretaris sebagai penguasa informasi:

Framing Devices:

1. Metaphors:

a. "Sekretaris berasal dari kata secret. Artinya, sekretaris adalah orang yang dipercaya untuk menjaga suatu data yang confidential" (paragraf 3 baris 1-2).

b. "Bayangkan jika para sekretaris ini iseng membocorkan informasi yang harusnya ia simpan"(paragraf 10 baris 3)

2. Eksemplars:

a. "Hanya mereka yang bisa mendapatkan akses informasi mendetail tentang suatu kasus atau masalah yang dihadapi perusahaan."(paragraf 10 baris 2)

b. "Maksudnya, hanya sekretaris yang berani masuk ruangan bos, lalu 'mengacak-acak' ruangan untuk mencari file". (paragraf 10 baris 2-3)

3. Catchphrases:

a. "information is power"(paragraf 11 baris 2)

b. "Maksudnya, hanya sekretaris yang berani masuk ruangan bos, lalu 'mengacak-acak' ruangan untuk mencari file". (paragraf 10 baris 2-3)

4. Depiction:

a. "Ada satu kehebatan yang dimiliki oleh orang-orang yang berprofesi sebagai 'secretary'. Hanya mereka yang punya akses ke dalam" (paragraph 10 baris 1)

5. Visual Image: -

Reasoning Devices:

1. Roots:

Fakta yang ingin ditonjolkan dalam bagian ini adalah bahwa akses informasi perusahaan secara mendetail ada ditangan seorang sekretaris. Sekretaris juga yang mempunyai wewenang untuk menyimpan datadata confidential sehingga bocor tidaknya sebuah informasi sangat tergantung pada sekretaris.

2. Appeal to Principle:

Penekanan pada kata yang berani, dapat membangun pemahaman bahwa hanya sekretarislah yang dapat keluar masuk ruangan bos dengan seenaknya, dan mengacak-acak dapat membangun 
pemahaman bahwa sekretaris mempunyai hak untuk dapat menyentuh data-data perusahaan dengan lebih bebas.

3. Consequences:

Bocor tidaknya sebuah informasi sangat tergantung pada sekretaris.

Analisa:

Femina Online mempresentasikan girl power dalam bingkai bagian ini adalah sebagai penguasa informasi. Hal ini merupakan sebuah kehebatan lain yang dimiliki oleh sekrteraris selain kekuasaan - kekuasaan wanita sebelumnya.

\subsection{Artikel II - 3 Wanita Penikmat} Teknologi (Rubrik Karir dan Keuangan Femina Online Edisi III Bulan Maret 2010)

Core Frames:

Artikel ini menceritakan tentang sudut pandang Femina Online bahwa IT bukan hanya untuk kaum pria saja, wanita pun dapat berkecimpung dalam bidang tersebut. Kemampuan IT kaum wanita tidaklah kalah jika dibandingkan dengan kaum pria dengan berbagai kelebihan wanita seperti, keluwesan, kemampuan berkomunikasi dan kepercayaan diri.

A. Bagian artikel yang menggambarkan representasi bahwa wanita mempunyai kemampuan yang tidak kalah dalam bidang IT adalah:

Framing Devices:

1. Metaphors:-

2. Eksemplar:

a. "Dalam bidang teknologi informasi (TI), wanita tak kalah dibanding pria. Kesabaraan, kepekaan, ketelitian, dan kepandaian berkomunikasi yang khas, menjadi kompetensi 'mahal' para wanita untuk berkarier di bidang ini" (paragraf 1 baris 2-4).

b. "Kemampuan wanita berperan penting di dunia TI, terwakili oleh Sylvia Efi Widyantari Sumarlin (44), ketua umum Asosiasi Penyelenggara Jasa Internet Indonesia (APJII)" (paragraf 2 baris 1-3).
3. Cathcphrases:

a. "Bukan Hanya untuk Pria"

4. Depiction:

a. "Untuk bidang engineering, memang benar, perbandingan pria dan wanitanya masih 5:1. Tetapi, untuk bidang-bidang yang lain, wanita lebih unggul" (paragraf 9 baris 2-3)

5. Visual Image: -

Reasoning Devices:

1. Roots:

Kemampuan wanita di bidang IT tidak kalah oleh kaum pria dikarenakan adanya kesabaran, kepekaan, ketelitian dan kepandaian berkomunikasi yang merupakan kompetensi mahal. Judul artikel ini yaitu 3 Wanita Penikmat Teknologi, menjadi gambaran bagi adanya representasi girl power yang coba di bingkai oleh Femina Online.

2. Appeals to Principle:

Pembenaran ditunjukan melalui contoh wanita yang sukses berkecimpung dalam bidang IT yaitu oleh Sylvia Efi Widyantari Sumarlin sebagai ketua umum asosiasi APJII.

3. Consequneces:

Konsekuensi dari pembingkaian pada bagian ini adalah di dunia IT dimana teknologi seolah olah bagaikan sulap, ditujukan bukan hanya untuk pria.

Analisa:

Pernyataan teks berita yang merupakan penyampaian ide girl power, disampaikan dengan contoh-contoh yang menjadi pembenar tentang kemampuan wanita yang tidak kalah oleh pria dalam dunia teknologi.

B. Bagian artikel yang menggambarkan representasi bahwa modal feminitas yang menguntungkan adalah:

Framing Devices:

1. Metaphors:-

2. Eksemplar:

a. "Percaya diri inilah yang membuat wanita bisa masuk dalam lingkungan TI, yang katanya didominasi para pria” (paragraf 9 baris 1-2) 
b. "Bidang lain yang dimaksud Efi adalah kreativitas sebagai web designer. "Urusan desain yang berhubungan dengan kreativitas, masih diangggap pria sebagai sesuatu yang feminin, karena membutuhkan kesabaran," (paragraf 10 baris 1-3)

c. "Peluang di bagian Training TI, yakni melakukan training pemasaran dan training produk, juga bisa dimanfaatkan, karena wanita memiliki kemampuan komunikasi yang baik".(paragraf 11 baris 4-5)

3. Catchpharse:-

4. Depiction:

a. "Wanita memiliki kelebihan-kelebihan yang berguna, di antaranya kemampuan berkomunikasi, kesabaran, dan multitasking. "Sejak kecil, wanita kan dididik untuk bisa mengerjakan banyak hal dalam waktu yang bersamaan, hal ini berguna sekali untuk diterapkan dalam dunia TI yang serba cepat dan dinamis" (paragraf 12 baris 2 -4).

5. Visual Image: -

Reasoning Devices:

1. Roots:

Femina membangun pembenaran pembenaran atas kemampuan wanita terjun dalam dunia IT karena modal feminitas sebagai bentuk girl power yang dimilikinya.

2. Appeals to Principles:

Klaim atas modal feminitas yang dimiliki perempuan seperti kemampuan komunikasi, kesabaran, ketelitian dan kesabaran. Juga adanya pelabelan terhadap kemampuan multi tasking wanita sejak kecil menjadi kelebihan yang berguna dalam dunia IT yang serba cepat dan dinamis.

3. Consequenses:

Konsekuensinya adalah bahwa untuk berhasil dalam bidang IT, multi tasking sangat diperlukan.
Analisa:

Pemakaian kata-kata seperti 'kompetensi mahal', 'bukan hanya untuk pria' menekankan arti dari sebuah pemaknaan atau menonjolkan kesan terhadap pemaknaan girl power. Pembenaran atas kesuksesan wanita dalam bidang IT melalui contoh dan kemampuan yang menentukan mengarah pada girl power.

\section{Intepretasi Penelitian}

Gagasan atau ide yang ditunjukkan berupa pernyataan-pernyataan teks berita dalam berbagai elemen framing devices, menunjukkan adanya representasi girl power dalam setiap artikel yang disajikan oleh Femina Online. Representasi girl power yang ditampilkan tersebut akan membentuk konsep tentang kekuasaan wanita dalam benak pembaca melalui konstruksi bahasa. Sehingga berdasarkan hasil analisis terhadap artikel 'Bukan Sembarang Sekretaris' dan '3 Wanita Penikmat Teknologi' intepretasi yang didapatkan oleh penulis adalah sebagai berikut:

1. Representasi girl power dalam artikel 1 berbentuk:

a. Posisi penting dalam perusahaan: wakil pimpinan, peninjau kebijakan, pengurus operasional perusahaan.

b. Problem Solver: mempunyai power advicer, mempunyai strategi, pemikir jalan keluar terbaik untuk setiap permasalahan perusahaan, penentu keputusan di saat darurat.

c. Garda Depan: wakil pimpinan, maju terlebih dahulu sebagai wakil perusahaan, wewenang untuk menyeleksi tamu.

d. Penguasa Informasi: keleluasaan untuk setiap informasi, wewenang untuk mengacak-acak ruangan pimpinan, penyimpan data-data confidential perusahaan, kekuasaan informasi. 
2. Representasi girl power dalam artikel 2 berbentuk:

a. Mempunyai kemampuan tidak kalah dengan pria: Kesabaraan, kepekaan, ketelitian, dan kepandaian berkomunikasi yang khas: sebagai sebuah kompetensi mahal.

b. Modalitas feminitas: kepercayaan diri, kreativitas, komunikasi, multi tasking.

\section{PENUTUP}

\section{Kesimpulan}

Dari hasil pembahasan dan intepretasi maka terdapat kesimpulan sebagai berikut: 1. Dalam bingkai Femina Online, profesi sekretaris direpresentasikan sebagai profesi yang tidak lagi dipandang sebelah mata atau remeh. Profesi yang notabene lebih banyak dikerjakan oleh kaum wanita tersebut ternyata sangat kental dengan girl power. Kekuasaan wanita atau girl power bahkan dapat ditemui dalam setiap elemen tugas yang dikerjakan.

2. Sementara wanita pun direpresentasikan oleh Femina dalam bingkai beritanya, dapat disejajarkan atau bahkan melebihi pria untuk berkarir di bidang IT.

3. Modal feminitas yang diperoleh sejak lahir merupakan girl power tersendiri, karena dengan kelebihan tersebut mereka dapat bersaing bahkan berkarir dengan jabatan lebih tinggi dari kaum pria di dalam dunia IT.

4. Femina mencoba membingkai konsep girl power, melalui konstruksi bahasa, pemakaian teks yang menunjukkan kekuasaan dan tekanan kuat untuk membentuk representasi tentang girl power.

\section{Saran}

Sebaiknya, penelitian tentang girl power tidak hanya dilihat dari kajian media tetapi mungkin juga melalui cultural studies atau kajian kritis. Pemilihan artikel juga hendaknya dilakukan dengan lebih spesifik pada profesi yang lebih tinggi jenjangnya. Perlu juga dilakukan wawancara terhadap pihak media untuk mendapatkan gambaran pembingkaian dengan lebih mendalam dan maksimal. Karena ternyata studi pustaka saja tidak mencukupi untuk menampilkan gambaran dari representasi girl power yang dimaksudkan.

\section{Daftar Pustaka}

Alex Sobur. 2002. Analisis Teks Media (Analisis Teks Media; Suatu Pengantar untuk Analisis Wacana, Analisis Semiotik dan Analisis Framing). Bandung: Remaja Rosdakarya.

Bhatnagar, D dan Rajadhyaksha, U. 2001. Attitudes toward work and family roles and their implication for career growth of women. Sex Roles: A Journal of Research.

Creswell, John W. 1998. Qualitative Inquiry and Research Design: Choosing Among Five Tradition, California: Sage.

Eriyanto. 2002. Analisis Framing: Konstruksi, Ideologi, dan Politik Media. Yogyakarta: LKIS.

Hall, Stuart. 1997. Representation: Cultural Representation and Signifying Practices. London: Sage Publications.

Hopkins, Susan. 2002. Girl Heroes: The New Force In Popular Culture. Annandale NSW: Pluto Press Australia.

Idi Subandi Ibrahim dan Hanif Suranto. 1998. Wanita dan Media, Konstruksi Ideologi Gender dalam Ruang Publik Orde Baru. Bandung: Remaja Rosda Karya.

Karlyn, Kathleen Rowe. 2003. Scream, Popular Culture, and Feminism's Third Wave: 'I'm Not My Mother'. Genders: Presenting Innovative Work in the Arts, Humanities, and Social Sciences No. 38. 
Patton, Michael Quinn. 2002. Qualitative Research \& Evaluation Methods 3rd Edition. California: Sage Publications. Rhenald Kasali. 1998. Membidik Pasar Indonesia: Segmentasi, Targeting dan Positioning. Jakarta: PT. Gramedia Pustaka Utama.

Nirwana. Juli 2001. Jurnal Vol 3, No. 2. Surabaya.
Rini JF. 2002. Wanita Bekerja, Jurnal Psikologi.

Siahaan. Juli 1998. Journal of Sociology Vol. 95, 'Willian A. Gamson and Andre Modigliani - Media Discourse and Public Opinion on Nuclear Power a Constructionist Approach”. 